\title{
Population dynamics of soil Acarina in natural and degraded forest ecosystem at Pathalipam, Lakhimpur, Assam
}

\author{
Minati Borah and L.N.Kakati \\ Department of Zoology, Nagaland University Lumami: 798627, Nagaland, India
}

\begin{abstract}
Population density of soil Acarina in natural and degraded forest sites were studied for one year at

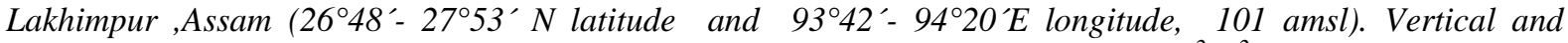
seasonal distribution of total soil Acarina were more in natural forest $\left(396.74 \times 10^{2} \mathrm{~m}^{-2}\right)$ than degrsded forest $\left(226.32 \times 10^{2} \mathrm{~m}^{-2}\right)$ and showed a significant decrease from upper layer to deeper layers $(0-30 \mathrm{~cm})$. In natural forest soil Acarina recorded higher population during rainy season (228.66 $\left.\times 10^{2} \mathrm{~m}^{2}\right)$, followed by summer $\left(108.74 \times 10^{2} \mathrm{~m}^{2}\right)$ and winter season $\left(59.34 \times 10^{2} \mathrm{~m}^{2}\right)$ than degraded forest respectively. While physical factors exhibited significant correlation with soil Acarina except relative humidity, some chemical factors were significant correlationship and some were insignificant relation wih soil Acarina.
\end{abstract}

Key words: population density of soil Acarina in different seasons and soil depth, Natural and Degraded forest ecosystem of Lakhimpur, Assam.

\section{Introduction}

Acarina was the very small free-living soil and litter microarthropods which was most abundant and dominant group in soil-litter sub system and plays an important role in sustaining forest ecosystem by maintaining the edaphic factors through decomposition and mineralization of leaf litter. The higher concentration of population density of soil Acarina in natural forest attributed to close canopy with vegetation cover, availability of food, accumulation of litter and optimum physico-chemical factors that favour optimum growth of acarine population, while disturbances and lack of canopy in degraded forest site have a negative impact on soil microarthropods community. Soil Acarina are divided into four sub orders viz. Cryptostigmata, Mesostigmata, Prostigmata and Astigmata. They are seen associated with highly organic, decomposing material such as manure. Reduction of vegetation cover and the consequent changes in microclimate has shown negative effects on survival and reproduction of soil microarthropods, however, abundance of soil microarthropods is ecologically important to maintain soil fertility status through decomposition and nutrient cycling for forest restoration (Seastedt, 1984; Badejo and Straalen, 1993; Wardle and Giller, 1996). Doulo and Kakati (2009) recorded higher population of soil micro arthropods in natural site exhibiting conspicuous vertical distribution and seasonal variation in both sites. Hence the present study was carried in natural and degraded forest ecosystem in the abundance, distribution, density and species diversity of soil and litter microarthropods in relation to certain climatic and edaphic factors in this region in Dulung reserve forest, Pathalipam, Lakhmpur district of Assam.

Study sites

\section{Materials and Methods}

The present investigation was carried out in two adjoining area of natural and degraded forest ecosystem in Dulung Reserve Forest of Lakhimpur district, Assam which lies at $26^{\circ} 48^{\prime}-27^{\circ} 53^{\prime} \mathrm{N}$ latitude and $93^{\circ} 42^{\prime}-94^{\circ} 20^{\prime} \mathrm{E}$ longitude at an altitude of $101 \mathrm{~m}$ above mean sea level, covering an area of 9900.23 hectre. While the natural forest site comprises of rich vegetation, the vegetation in degraded forest site is comparatively thin vegetation due to human activities and occasional logging of forest tree. The first dominant trees species that form the canopy layer is Keyia assamica (30\%). The second dominant trees are Mesua ferrea (15\%). The smaller trees are belong to the families of Lauraceae, Euphobiaceae, Araliaceae, Ficaseae and Rubiaceae having 5 to $15 \mathrm{~m}$ height and shrubs are Alpinia allughas, Alpina pudica L. Calamus erectus (Climber), Calamus viminalis, Leucas lavandulaefolia Sm. Solanum indicum L., Clerodendrum viscosum Vent. Clerodendrum serratum (L), etc. Very small plants i.e., herbs are Centella asiatica L., Mimosa pudica L., Coix lacrymal- jobi L. Job's tears, were found abundantly in natural site while degraded forest was mostly represented by less herbs, shrubs etc due to diturbances of human being.

\section{Climate}

The climate of the area is monsoonic with three distinct seasons i.e. summer, rainy and winter. The ombrothermic data (Fig. 1) based on twenty years (1987-2006) highlights the climatic condition of Lakhimpur district which reveals that June to September constitute rainy seasons while October to May comprise dry 
Population dynamics of soil Acarina in natural and degraded forest ecosystem at Pathalipam,

period. The dry period can be further divided into moist summer (February to May) and cool dry (October to January) season. Thus there is distinct summer (February to May), rainy (June to September) and winter (October to January) seasons. While February constitute the transitional month between winter and summer, October is the transitional month between rainy and winter season.

The meteorological data during the study period from October 2006 to September 2007 is shown in (Fig.1). The average minimum and maximum air temperature was recorded in the month December, 2007 $\left(9.10^{\circ} \mathrm{C}\right)$ and August, $2007\left(34.03^{\circ} \mathrm{C}\right)$ respectively. The maximum relative humidity was recorded in the month July, 2007 (96.73\%) and the minimum was (26.03\%) in the month June, 2007 at 8-30 hours. The highest record was of $91 \%$ in the month of July, 2007 and the lowest was recorded in the month of April, 2007 of (52.4 \%) at 17-30 hours. The maximum annual rainfall during the study period was recorded in the month of June $(853.8 \mathrm{~mm})$ and minimum in the month of December and January $(13.3 \mathrm{~mm})$. The total annual rainfall was $3753 \mathrm{~mm}$.

\section{Sampling and extraction}

In both the natural and degraded forest ecosystem, the sampling collection sites are divided into lower, middle and upper elevation site. Each site is further divided into three different plots having an area of $10 \mathrm{~m} \mathrm{x}$ $10 \mathrm{~m}$ size which are approximately $25 \mathrm{~m}$ to $30 \mathrm{~m}$ apart from each other. Soil samples for microarthropods were collected from each area at different soil depths i.e. $0-10 \mathrm{~cm}, 10-20 \mathrm{~cm}$ and $20-30 \mathrm{~cm}$ by using soil corer with sampler size of $3.925 \mathrm{~cm}^{2}$ (10 cm in height and $5 \mathrm{~cm}$ in diameter). Sampling for soil Acarina was initiated in October, 2006 and continued till September, 2007 with an interval of one month. All the sampling was done in the morning between 9:00am and 11:00am in mid week of the each month. Three replicates one from each area was collected from upper, middle and lower elevation sites from both ecosystems. As such, 324 samples (three replicates one from each area was collected from upper, middle and lower elevation ) were collected from each ecosystem for 12 months during study period. For analysis of physico-chemical characteristics, soil samples were also collected in similar manner from the adjacent sampling area of Acarina. After collection, each sample was immediately transferred into individual polythene bag, labeled and packed to avoid moisture loss and any kind of disturbance to Acarina during its transit period. The samples were immediately brought to the laboratory and Acarina were extracted with the help of modified Tullgren funnel as described by Crossley and Blair (1991). Soil Acarina were extracted into collecting vial, containing 70\% ethanol, transferred into a petridish, identified and counted into various taxa with the help of binocular microscope and densities me calculated.

\section{Soil analysis}

Physico-chemical characteristics of soil such as temperature, moisture, $\mathrm{pH}$, organic carbon, total nitrogen, available phosphorus, and potassium were analysed during each sampling period in order to study the impact of these factors on the population changes of microarthropods. Soil temperature was recorded with the help of soil thermometer; Soil moisture content was determined by gravimetric method (Misra, 1968 and Wilde et al,1985); Soil $\mathrm{pH}$ was determined by using a portable glass electrode $\mathrm{pH}$ meter (Anderson and Ingram, 1993); soil organic carbon was determined by modified Walkey and Black method (Anderson and Ingram, 1993); Soil total nitrogen was determined by acid digestion Kjeldahl procedures (Anderson and Ingram, 1993); Soil available phosphorus was determined by ammonium molybdate stannous chloride method (Sparling et al, 1985); Soil potassium and sodium were determined by flame photometer (Steward, 1971). Data on monthly rainfall, relative humidity and air temperature were measured in the field during the study period.

\section{Result and Disussion}

Acarina was found to be dominant group comprising $39.26 \%$ and $37.51 \%$ of the total soil microarthropods in natural and degraded sites respectively. Higher abundance of Acarina among soil microarthropods were also reported in different forest ecosystem (Ryke and Loots, 1967; Mitchell, 1977; Wallwork, 1983; Sarkar, 1991). Chitrapati (2002) reported that Acarina comprised 66\% and $63 \%$ of total soil microarthropods. Doulo (2007) also reported that Acarina comprised $42.4 \%$ and $40.8 \%$ of the total soil microarthropods in natural and degraded in forest sites respectfully in Lumami, Nagaland. The Acarina population was recorded to be 1.75 times higher in the natural forest $\left(396.74 \mathrm{x}_{10} \mathrm{~m}^{-2}\right)$ than the degraded site $\left(226.32 \times 10^{2} \mathrm{~m}^{-2}\right)$ Table 1. Hazra (1991) also reported a decrease in population percentage of mites in deforested site as compared to the reserve forest. Wood (1960) reported that organic matter together with the moisture present in the soil made a condition highly favourable for higher concentration of mites. Morris (1978) also recorded higher concentration of soil fauna in ungrazed site than grazed site.

Monthly variation of total population density of Acarina exhibited similar trend in both natural and degraded forest. With the initial record of $24.68 \times 10^{2} \mathrm{~m}^{-2}$ and $15.27 \times 10^{2} \mathrm{~m}^{-2}$ during October, the number decreases to minimum during January $\left(5.90 \times 10^{2} \mathrm{~m}^{-2}\right.$ and $\left.1.93 \times 10^{2} \mathrm{~m}^{-2}\right)$ in natural and degraded forest respectively and gradual increases in both natural and degraded forest reaching the peak during August (70.77 
Population dynamics of soil Acarina in natural and degraded forest ecosystem at Pathalipam,

$\mathrm{x} 10^{2} \mathrm{~m}^{-2}$ and $40.08 \times 10^{2} \mathrm{~m}^{-2}$ respectively) (Fig. 2). In both study sites, maximum population growth during rainy season reached the peak in August. This may be due to favorable, physico-chemical factors i.e. optimum condition of moisture, organic carbon content etc during rainy season as the population buildup of soil microarthropods is influenced by a variety of factors viz., vegetation, soil, climate etc. and their interaction (Narula et al, 1998). Badejo et al. (1997) reported maximum population of Acarina when there was high moisture content. Loots and Ryke (1966) reported minimum population during winter season. Many workers have also reported higher population of soil microarthropods during rainy season and a sharp decline during summer months (Sanyal 1996; Reddy and Venkataiah 1990).

The seasonal vertical distribution pattern also showed a decreasing trend with increase in soil depth in both study sites (Fig. 3 a,b). Soil Acarina in the upper soil layers was primarily found to be influenced by moisture content and secondarily by temperature conditions (Strong, 1967). In the present investigation also similar pattern was observed in the population density of Acarina representing maximum in the upper soil layer at $0-10 \mathrm{~cm}$. The seasonal variation of Acarina in both sites in the present investigation may be attributed to cumulative effect of all physico-chemical factors rather than a single factor influence. Petersen (1980) and Hagvar (1983) had also shown that the higher densities of micro-arthropods population occurred in the upper layers of the soil. Hattar et al. (1998) and Chitrapati (2002) also reported maximum population of Acarina during rainy season and observed decreasing trend with the on set of winter. Acarina population in natural forest ecosystem showed maximum density in the month of August in $0-10 \mathrm{~cm}$ during raining season and minimum in $20-30 \mathrm{~cm}$ in winter season. Natural forest had higher population density of $19.18 \%, 68.47 \%$ and $123.45 \%$ in $0-10 \mathrm{~cm}, 10-20 \mathrm{~cm}$ and $20-30 \mathrm{~cm}$ layer respectively than degraded site. Higher population density at $0-10 \mathrm{~cm}$ layer $(>47 \%$ in natural and $66 \%$ in degraded site) may be due to climatic influence, adequate living space, favourable moisture condition, aeration rate and accumulation of nutrient in humus soil (Reddy and Venkataiah,1990). However sharp declination of population density in lower soil layers of $10-20$ and $20-30 \mathrm{~cm}$ in degraded site than natural site may be attributed to poor living space, insufficient food resources and inimical microclimatic condition which results in maximum migration to top layer. Doulo and Kakati (2009) also recorded over $46 \%$ and $54 \%$ of microarthropods at $0-10 \mathrm{~cm}$ layer in natural and degraded site respectfully. Except for $0-10 \mathrm{~cm}$ (rainy and summer season) and $20-30 \mathrm{~cm}$ (winter) summer season, analysis of varience showed significant seasonal difference among other soil depths in degraded site while in natural forest difference was significant in all soil depths except in $20-30 \mathrm{~cm}$ during summer season.

Soil Acarina was positive relationship between temporal variation of different physical factors in both natural and degraded forest ecosystem except for relative humidity.

Air temperature, soil temperature, soil moisture showed highly significant positive correlation with Acarina, $(\mathrm{p}<0.001)$ and also statistically to show the effect of abiotic factors on fluctuation in both natural and degraded forest ecosystem except relative humidity.

The positive correlation between soil temperature and Soil micro arthropods such Collembola and Acarina in natural and degraded forest ecosystem from Imphal Valley has been reported by (Mukharji and Singh, 1970; Mitra, 1977; Bhattacharya and Raychoudhuri ,1979; Choudhuri and Pande,1979; Sanyal,1982; Reddy ,1984 Narula, 1998; Chitrapati, 2002). It appears that the pattern of the temporal changes in the abundance of soil microarthropods vary from area to area depending on the local micro climatic conditions.

In the present investigation also similar pattern was observed in the population density of Acarina representing maximum in the upper soil layer at $0-10 \mathrm{~cm}$. The seasonal variation of Acarina in both sites in the present investigation may be attributed to cumulative effect of all physico-chemical factors rather than a single factor influence. Petersen (1980) and Hagvar (1983) had also shown that the higher densities of microarthropods population occurred in the upper layers of the soil. Hattar et al. (1998) and Chitrapati (2002) also reported maximum population of Acarina during rainy season and observed decreasing trend with the on set of winter. The results of the present investigation showed close similarities and strikng differences with the observations made by earlier workers which may be attributed to the local microclimatic factors varing from plot to plots (Wall work, 1970). Thus it was the cumulative effects of various climatic and edaphic factors which influenced on the temporal changes in the abundance of soil microarthropods (Badejo and Straalen, 1993).

Table 1: Seasonal variation of Acarina (Numbers \pm S.E.) $x 1^{2} \mathrm{~m}$ in natural and degraded forest ecosystem at Pathalipam, Lakhimpur.

\begin{tabular}{|c|c|c|c|c|}
\hline \multirow[t]{2}{*}{ Forest Type } & \multirow[t]{2}{*}{ Season } & \multicolumn{2}{|r|}{ Soil layers } & \multirow[t]{2}{*}{ Total } \\
\hline & & $10-20 \mathrm{~cm}$ & $20-30 \mathrm{~cm}$ & \\
\hline \multirow{5}{*}{ Natural } & Winter & $32.05 \pm 1.69$ & $17.25 \pm 1.04$ & $59.34 \pm 3.10$ \\
\hline & Summer & $55.16 \pm 3.07$ & $35.17 \pm 1.72$ & $108.74 \pm 2.21$ \\
\hline & Rainy & $101.39 \pm 3.52$ & $43.67 \pm 1.43$ & $228.66 \pm 2.04$ \\
\hline & Annual & $188.60 \pm 1.33$ & $136.02 \pm 1.20 \quad 72.12 \pm 0.69$ & $396.74 \pm 3.63$ \\
\hline & & $\mathrm{a}=47.54 \%$ & $18.18 \%$ & $100 \%$ \\
\hline
\end{tabular}


Population dynamics of soil Acarina in natural and degraded forest ecosystem at Pathalipam,

\begin{tabular}{|l|l|rrrr|r|}
\hline \multirow{5}{*}{ Degraded } & Winter & $20.17 \pm 1.12$ & $8.28 \pm 0.88$ & $4.02 \pm 0.11$ & $32.47 \pm 1.20$ \\
\cline { 2 - 7 } & Summer & $51.65 \pm 3.64$ & $13.67 \pm 2.15$ & $7.37 \pm 0.36$ & $72.69 \pm 1.27$ \\
\cline { 2 - 7 } & Rainy & $78.87 \pm 1.74$ & $28.87 \pm 0.42$ & $13.42 \pm 3.28$ & $121.16 \pm 4.06$ \\
\cline { 2 - 7 } & Annual & $150.69 \pm 1.05$ & $50.82 \pm 3.78$ & $24.81 \pm 4.11$ & $226.32 \pm 3.27$ \\
\cline { 2 - 6 } & & $\mathrm{a}=66.58 \%$ & $22.46 \%$ & $10.96 \%$ & $100 \%$ & \\
\hline
\end{tabular}

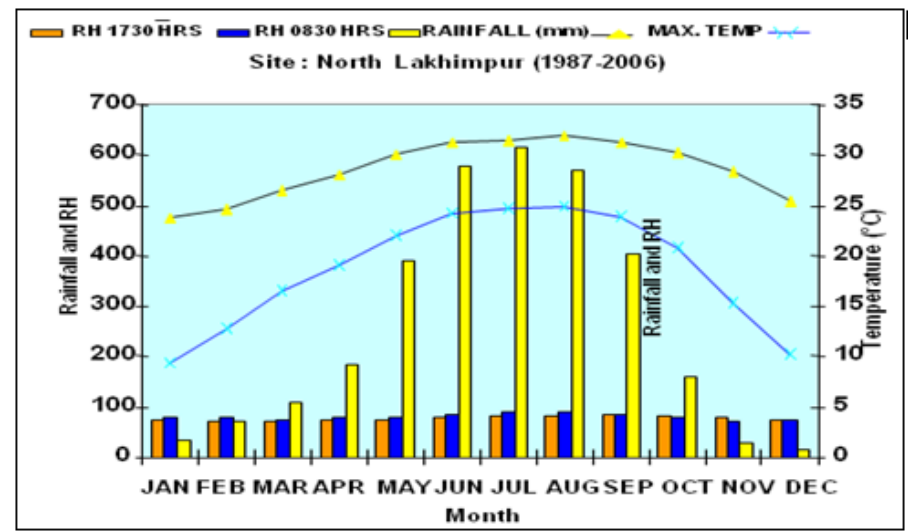

Fig. 1: Ombrothermic diagram based on twenty years (1987-2006)

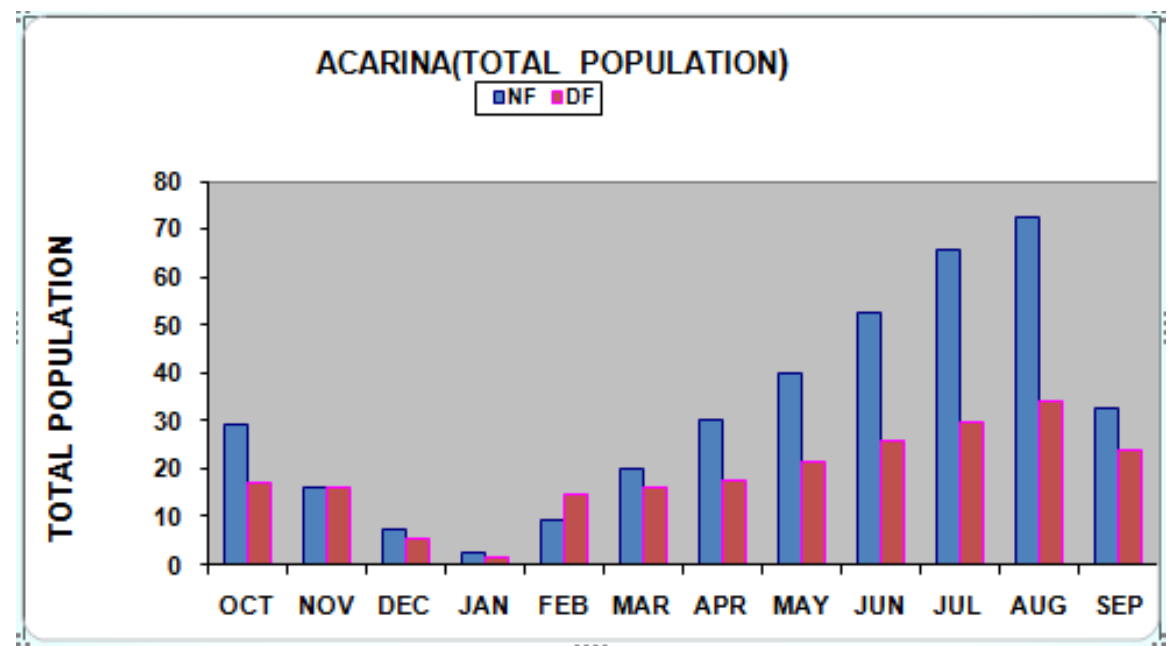

Fig. 2: Monthly fluctuation of total Acarina population density (Numbers $x_{10} \mathrm{~m}^{2}$ ) in natural (NF) and degraded (DF) forest ecosystem.

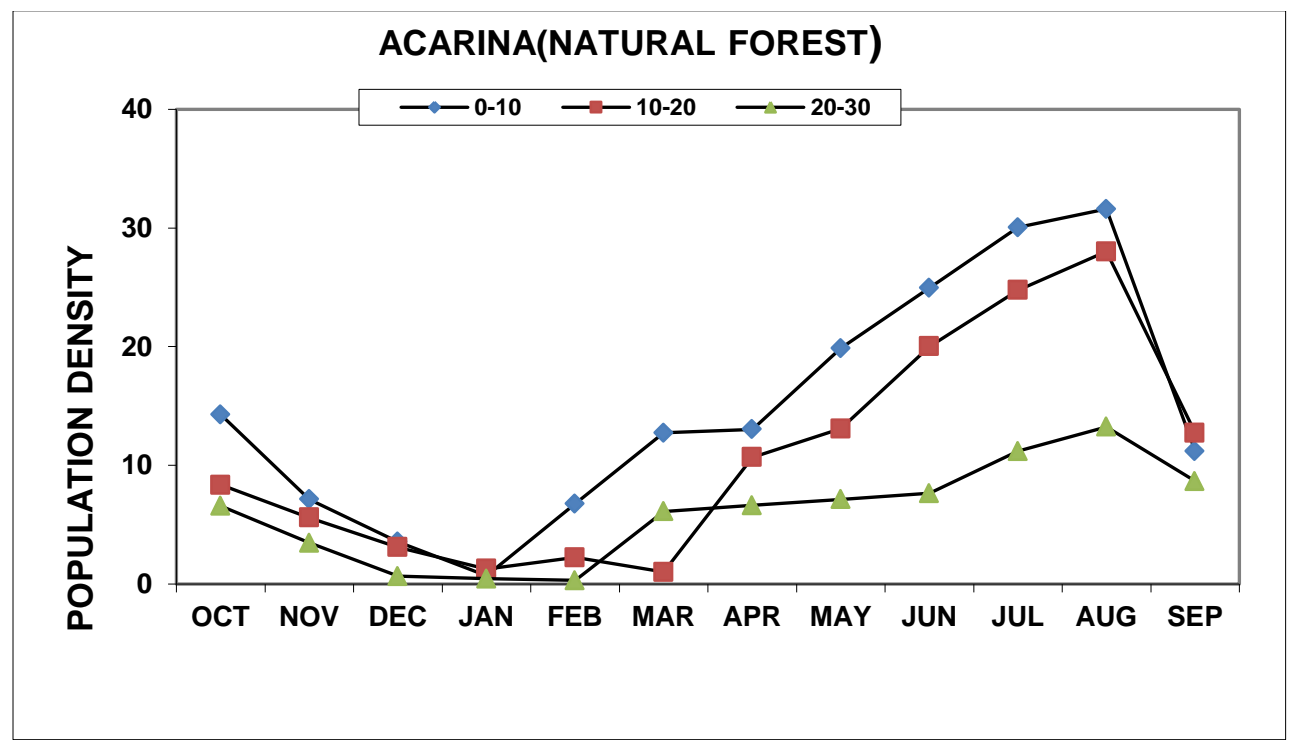




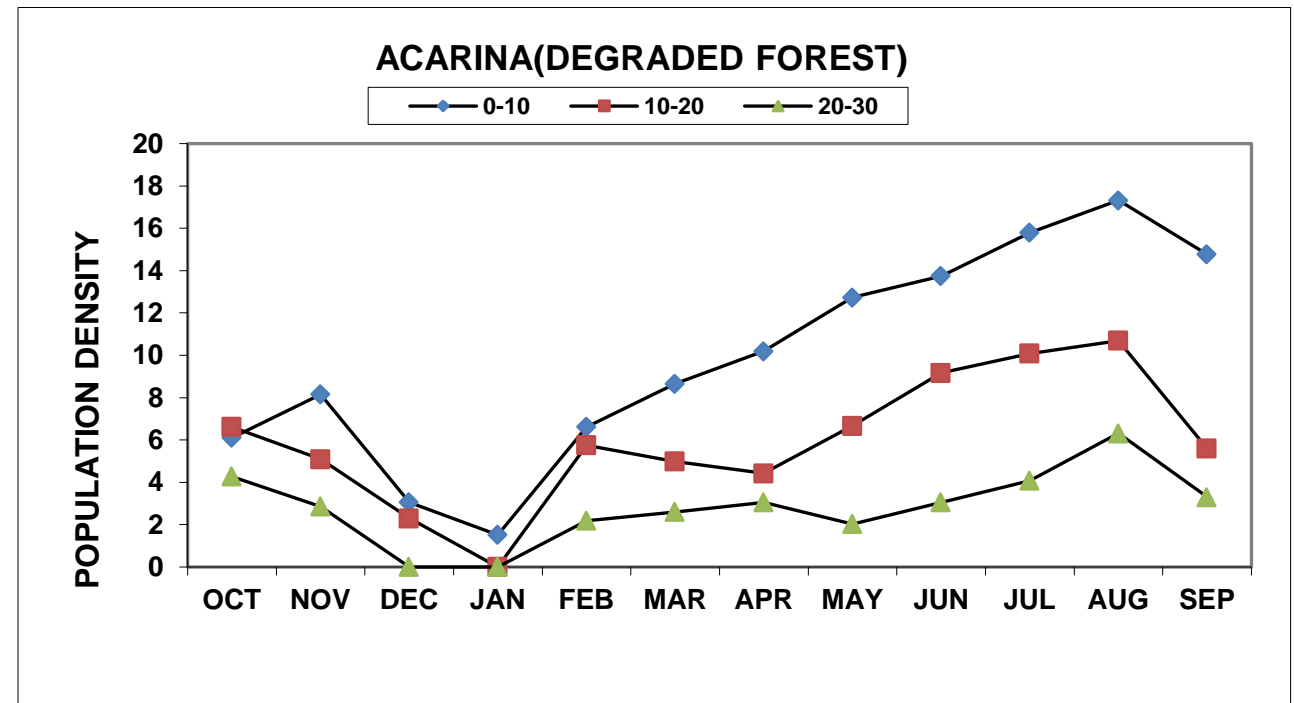

Fig. 3: Monthly vertical distribution of total Acarina population density (Numbers $\times 10^{2} \mathrm{~m}^{-2}$ ) in different soil layers of (a) natural (NF) and (b) degraded (DF) forest ecosystem

\section{References}

[1]. Alfred, J.R.B., V.T. Darlong, S.J.S. Hattar, and D. Paul, 1991. Microarthropods and their conservation in some North- East Indian soil, In (Eds. G.K. Veeresh, D. Rajagopal and C.A.Virak Tamath): Advances in Management and conservation of soil fauna, Bangalore.

[2]. Anderson, J.M. and J. S. Ingram I Eds., 1993. Tropical soil Biology and Fertility : A hand book of Method, U.K. C.A.B., International.

[3]. Aoki, J. I., 1967. Microhabitats of Oribatid mites on a forest floor, Bull, Nat. Sci., Mus. Tokyo, 10:133-138

[4]. Badejo, M.A. and N.M. Van Straalen, 1993. Seasonal abundance of springtails in two contrasting environment. Biotropica, 25: 222-228.

[5]. Behan-Pelletier, V. M. and Walter, D. E., 2000. Biodiversity of Oribatid mites (Acari: Oribatida) in tree canopies and litter. In: D. C. Coleman and P. F. Hendrix (eds). Invertebrates as Webmaster in Ecosystems, CAB International. Wallingford and New York: 187-202.

[6]. Badejo, M.A., T.O. Obilade and B.A. Oblubakin, 1997. Spatial distribution and abundance of mites and springtails under temperature and moisture regimes in a tropical rain floor. Tropical Ecology, 38 (1):31-38.

[7]. Banerjee, S.,1973. Seasonal variations of Acari and soil nitrate. Acta Arachnol, 25(1):37-40.

[8]. Bhattacharya, T. and D.N. Raychoudhuri, 1979. Monthly variation in the density of soil microarthropods in relation to some climatic and edaphic factors. Entomon, 4(4):313-318.

[9]. Chitrapati, C., 2002. Ecological study of soil microarthropods in the sub-tropical forest ecosystem at Khonghapat, Manipur. Ph. D. Thesis, Manipur University.

[10]. Crossley, Jr., D.A and J. Blair, 1991. A high efficiency, "Low technology" Tullgren-type extractor. Agric. Ecosyst. Environ., 34, 187-192.

[11]. Doulo, V., 2007. Population dynamics of microarthropods and effect of soil nutrients in natural and degraded forst ecosystem at Lumami, Nagaland. Ph. D. Thesis, submitted to Nagaland University.

[12]. Doulo, V. and L.N. Kakati,, 2009. Vertical distribution and seasonal variation of soil microarthropods in natural and degraded forest ecosystem at Lumami, Nagaland.. J. Soil Biol. Ecol., 29:126-138.

[13]. Gupta, G.P. and S.P. Mukharji, 1976.Qualitative composition of the fauna of cultivated and uncultivated soil. Indian J. Ent., 38: 313-324.

[14]. Hagvar, S.,1983. Collembola in Norwegian coniferous forest soil,1I- vertical distribution. Pedobiologia, 25:383-401.

[15]. Hattar, S.J.S. and J.R.B. Alfred and V.T. Darlong, 1998. Animal diversity in some managed and protected forests of North-East India with particular reference to soil fauna. (Eds by P.C. Kotwal and S. Banerjee).Pp.108-118, Agro Botanica, Bikaner.

[16]. Hazra, A.K., 1991. Effect of deforestation on the soil macro-microarthropod fauna of West Bengal, India, In: Advances in Management and conservation of soil fauna, (Eds, G.K. Veersh, D. Rajagopal and C.A. Viraktamath) Bangalore, pp. $399-411$.

[17]. Hazra, A. K. and Sanyal, A. K., 1996. Ecology of Collembola in a periodically inundated newly emerged alluvial island in the river Hoogly, West Bengal. Proceeding Zoological Society Calcutta. 49 :157- 169.

[18]. Loots, G.C. and P.A.J. Ryke, 1966. A comparative quantitative study of the microarthropods in different types of pasture soils, Zool., Afr. 21: 157 - 197.

[19]. Metz, L.J., 1971. Vertical movement of Acarina under moisture gradient. Pedobiologia, 11: 262-268.

[20]. Misra, R., 1968. Ecology Work Book, Oxford and IBHpub. Co. Calcutta, Indi.

[21]. Mitchell, M.J., 1977. Population dynamics of Oribatid mites (Acari : Cryptostigmata) in an aspen woodland soil. Pedobiologia, 17:305-319.

[22]. Narula, A., L.K. Vats and S.Handa., 1998. Collembolans and mites of eciduous forest stand, Indian Journal of foresty. 21(2): 147 - 149. Nguyen, T. T. and M.Q.Vu.1988.A population density and distribution of microarthropods (Microarthropoda: Acari, Collembola and others) in soils of tropical forest of plateau Tay Nguyen (Central Vietnam). USSR Journal of Ecology, 2:73-75.

[23]. Niijima, K., 1971. Seasonal changes in Collembolan population in a warm temperate forest of Japan. Pedobiologia, 11:1126.

[24]. Norton RA., 1994. Evolutionary aspects of oribatid mite life histories and consequences for the origin of the Astigmata. Mites: Ecological and Analysis of Life-History Patterns, ed. M Houck, pp. 99-135. New Evolutionary York: Chapman and Hall. 
Population dynamics of soil Acarina in natural and degraded forest ecosystem at Pathalipam,

[25]. Petersen, H., 1980. In: Soil Biology as related to land use practices, Dindal D.L.(ed). Proc. VIII Int. Soil Zool., Colloq. Pp. 806833.

[26]. Rajagopal, D., 2011.Distributionof Mesostigmatid mites species in different habitats of Western Ghats. J. Soil Biol.Ecol., 31(1\&2):139-143

[27]. Reddy, M.V. and B.Venkataiah, 1990. Effect of tree plantation on seasonal community structure of soil microarthropods in a tropical semi rid Savana, Trop. Ecol., 31:96-105.

[28]. Ryke, P.A.J. and G.C. Loots, 1967. The composition of the microarthropods fauna in South Africa soils. In Otto Graff and John E. Satchell, (eds). Progress in Soil Biology, Friedr. Vieweg and Sohr. Gmph, Brauchweig. 528-546.

[29]. Sanyal, A.K., 1982. Soil Oribatid mites and their relation with soil factors in West Bengal, J. Soil Biol. Ecl., $2(1): 8-17$.

[30]. Sarkar, S., 1991. Studies on microarthropod community in one undisturb habitat of Tripura with special reference to oribatid mites, In: Advances in management and Conservation of soil.

[31]. Seastedt, T.R., 1984. The role of microarthropods in decomposition and mineralization processes, Ann. Rev. Entom., 29: 25 -46 .

[32]. Sheals, J.G., 1957.The Collembola and Acarina of uncultivated soil. J. Animal Ecol., 26:125-134.

[33]. Sinha, P.B., N.S. Sen and H.A. Jafri, 1988. On the seasonal population of Collembola and Acarina in a deciduous forest at Ranchi, J. Environ. Biol., 9(1 suppl.).79-83.

[34]. Sparling, G.P., K.N. Shale, and A.J., 1985. Quantifying the contribution from the soil microbial biomass to the extractable levels of fresh and air dried soils, Aust. J. of Soil, Res. 23:613-621.

[35]. Steward, E.A., 1971.Chemical analysis of ecological materials, Blackwell Scientific publication, Oxford.

[36]. Strong, J., 1967. Ecology of terrestrial arthropods at Palmer Station, Antarctic Peninsula., Anterctic Res. Ser. 10:357-71.

[37]. Wallwork, J.A, 1970. Ecology of soil animals, Mc graw- Hill publishing company limited. 283 pp.

[38]. Wallwork, J.A, 1976. The Distribution and Diversity of Soil Fauna, Academic Press. London-New York-San Francisco. $27-54$. $355 \mathrm{pp}$.

[39]. Wallwork, J.A, 1983. Oribatids in forest ecosystems, Annual Review of Entomology., 28:109-139.

[40]. Wardle, D.A. and K.E.Giller, 1996. The quest for a contemporary ecological dimension to soil biology- Discussion. Soil biology and biochemistry, 28:1549-1554.

[41]. Wilde, S.A., R.B.Corey, J.G. Iyer and G.K. Viogt., 1985. Soil and plant analysis for tree culture, Oxford and IBH pub. Co. New Delhi.

[42]. Wood, F.W., 1960. Biological Antagonism due to phytotoxic root exudates. Bot., Rev. 26:546-569. 